\title{
Using of Natural Raw Material Mixture and Magnetite Raw (Magnetic Iron) as Substitute for Chemical Fertilizers in Feeding "Le Conte" Pear Trees Planted in Calcareous Soil
}

\author{
Eman S.A ${ }^{1}$; W.M. Abd EL-Messeih ${ }^{2}$ and G.B.Mikhael ${ }^{3}$
}

\begin{abstract}
The present work was carried out during 2008 and 2009 years to investigate the possibility of utilization of natural raw mineral mixture (NRMM) and magnetite raw (magnetic iron) as a substitute for chemical fertilizers for feeding "Le Conte" pear trees planted in calcareous soil.The trial was conducted in Nubaria area El -Bohira Governorate.Trees were 7 years old, budded on communis rootstock and spaced at $4 \times 5$ m.apart. Eight treatments beside the control were used [ 4 NRMM treatments +4NPK treatments], all treatments, except the control were received magnetite raw as follows: $250,500,750$, and1000gm /tree.
\end{abstract}

The comparison among NRMM and NPK treatments cleared the following points:

- NPK treatments significantly increased shoot diameter in both studied years and shoot length in the first year only, while the differences for shoot number and leaf area were not statistically significant NPK treatments also, significantly enhanced leaf total chlorophyll (SPAD) in 2009.

- NPK treatments induced high significant leaf N\% in both studied seasons and leaf $K \%$ and $P \%$ in 2008 only.

- NRMM treatments significantly increased leaf Mn and Zn in both growing seasons, while NPK treatments significantly enhanced leaf $\mathrm{Fe}$ in the two years.

- NPK treatments induced significant high fruit yield/tree in the two seasons; meanwhile the differences between NPK and NRMM treatments for fruit quality were not statistically significant.

- Increasing the applied rate of magnetite raw/tree significantly increased vegetative growth, leaf total chlorophyll, leaf mineral composition, yield and fruit quality.

- Fruit analysis revealed that the heavy metals (cobalt, nickel and lead) were in the permissible limits.

- The cost of the NPK treatments was nearly twice the cost of NRMM treatments. Using natural raw mineral mixture and magnetite raw as a substitute for chemical fertilizers for feeding "Le Conte" pear trees were reasonable but it needs more studies.

\section{INTRODUCTION}

\footnotetext{
${ }^{1}$ Horticultural Research Institute Agricultural Research Center- Egypt. ${ }^{2}$ Nubaria Hort. Res. Station, Hort.Res.Instit. Agric. Res. Center, Egypt. ${ }^{3}$ Sakha Res. Station, Hort. Res. Instit,,Agric. Res. Center, Egypt. Received Febuary28, 2010, Accepted March 21, 2010
}

Deciduous fruit trees and "Le Conte" pear trees as well, need essential elements in order to complete its life cycle with high production of good quality; these elements must be found essential for a wide range of higher plant species. The status of essential mineral nutrients in plant tissue, when properly understood, provides a useful tool for the growers, because the amount of each element in the plant determines plant performance. To be in proper balance and intensity for maximum yield, each element should be with specified concentration limits. Below these limits, there is a deficiency of the element, above them, there is an excess, possibly even a toxic excess. Soil tests, including determination of base saturation $(\mathrm{Ca}, \mathrm{Mg}, \mathrm{K}$, $\mathrm{Na}$ ), are of value for estimating nutrient availability and adverse $\mathrm{pH}$ (alkaline) or salt content. But since leaves are the important synthesis centers of plants, tests of leaves more nearly reflect the nutritional status of a plant than do tests made on soil. Because of, these essential elements must be found in sufficient quantity, and no other element can completely substitute for it, we need fertilizers to have fruit trees of good growth and productivity. On the other side, the financial, healthy and agricultural policy directs from not too long time to fertilize the soil and the product without harming the environment or the human's health. Studies carried out by the developed countries in the environment and in the general health field have approved that traditional methods in fertilization that depend basically and for a long time on chemical fertilizers have got side effects on the soil and the environment, eventually on human because of the diseases caused by them. As results of chemical fertilizers misuse, the nature of the agricultural land is changed and exhausted. Therefore, the alternative use of natural elements compound with organic manure fertilizers are improve the soil physical, chemical and properties, as well as, increased nutrient availability (Helail et al.,2003). For keeping in touch with the policy of providing substituents for the importing fertilizers that have good qualities with competing prices, Al-Ahram Company for Mining introduced the high quality Egyptian product that approved its high 
efficacy for ten years in different kinds of soils that subdue to periodical check. This lead to a great effect on demanding to use the Egyptian product by many farms, owners and many companies of clean and organic agriculture around Egypt. In order to reduce the dependence on imported potash, feldspar a potash mineral, contains $11.25 \% \mathrm{~K}_{2} \mathrm{O}$ and there fore it could be a potential k-source for crop production (Badr, 2006). On the other side, applying organic manures in calcareous soils are very important method for providing the plants with their nutritional requirements without having an undesirable impact on the environment).

Thus, the present work was imposed to study the using of natural raw mineral mixture and magnetite raw (Magnetic iron) as substitute for feeding "Le Conte" pear trees planted in calcareous soil. The main target is to produce a suitable fruit yield of good quality with reducing the cost without harming the environment or the human's health.

\section{MATERIALS AND METHODS}

The present study was carried out during two successive seasons, (2007-2008) and (2008-2009), on 7 years old "Le Conte" pear trees (Pyrus communis L.x Pyrus pyrifolia N.)on Pyrus communis rootstock planted in calcareous soil in a private orchardS at Nubaria area El-Bohira Governorate. Some physical and chemical analyses of the experimental soil is illustrated in Table (1).

Chemical analysis of the natural raw mineral mixture was done at the ministry of petroleum, the Egyptian Mineral, Resources Authority, central laboratories sector, on 22/11/2007. Table (3) illustrated the chemical analysis of natural raw mineral mixture.

The treated trees were spaced at $4 \times 5 \mathrm{~m}$. apart and were healthy and similar in their vigor, as possible, and were under flood irrigation. The selected trees (54 trees) were received the following treatments: Table (4).

\section{A-Vegetative growth measurements:}

Four main branches as uniform as possible were selected at the four cardinal points of each tree, tagged and the average of the current shoot number on the selected branch was counted, their length and diameters were measured on the first of November, leaf area was determined in mid July, using leaf area meter (Model Cl-203, CID, Inc, USA).

\section{B-Leaf chemical contents determination:}

\section{Determination of leaf total chlorophyll content:}

Leaf total chlorophyll content was determined by using MTNOLOTA CHLOROPHYIl METER SPAD502 (Minolta camera co. LTD JAPAN).

Ten readings were taken on ten leaves (the fourth leaf of the new shoot) of each experimental tree on mid June. The readings were taken at the middle of leaf blade (Westwood, 1988).

\section{Determination of leaf mineral composition:}

To determine leaf chemical status, samples of twenty mature leaves were collected at random, at the beginning of July in the two years of study. The leaves were washed several times with tap water, rinsed three times in distilled water, and then dried at 70-80 $\mathrm{C}$ in an electric air-drying oven. The dried leaves of each sample were ground in a porcelain mortar to avoid contamination with any minerals; $0.3 \mathrm{gm}$ from the ground dried material of each sample was digested with $\mathrm{H}_{2} \mathrm{O}_{2}$ and $\mathrm{H}_{2} \mathrm{So}_{4}$ according to Evenhuis and Dewaard (1980). Suitable aliquots were then taken for mineral determination. Total nitrogen and phosphorus were determined colorimetrically according to Evenhuis (1976), and Murphy and Riely (1962), respectively. Potassium was determined against a standard, using Air Propane Flame Photometer (Chapman and Pratt, 1961). Calcium and magnesium were measured, using, versinate method (Chang and Bray, 1951) and iron, manganese and Zinc by a Perkin-Elmer Atomic Absorptoion Spectrophotometer model 305-B. The concentrations of $\mathrm{N}, \mathrm{P}, \mathrm{K}, \mathrm{Ca}$ and $\mathrm{Mg}$ were expressed as percent, while those of iron, manganese and zinc were expressed as parts per million (ppm), on dry weight basis

\section{C-Determination of yield and fruit quality:}

Analysis of mature fruit was carried out when fruits of control attained maturity according to stands recorded by El-Azzouni et al.1975.

The total yield of each studied tree was determined as weight, in (kgs) at the harvest time in August of both studied years. Twenty mature fruits from each studied tree were taken at random for determining fruit quality.

Table 1. Some physical and chemical analysis of the experimental soil

\begin{tabular}{|c|c|c|c|c|c|c|c|c|c|c|c|}
\hline Texture & pH & $\begin{array}{l}\text { EC } \\
\text { Ds/m }\end{array}$ & $\begin{array}{l}\text { Total } \\
\text { CaCO }\end{array}$ & O.M. & $\begin{array}{l}\text { Total } \\
\text { N \% }\end{array}$ & $\begin{array}{c}\text { Soluble } \\
\text { Ca }\end{array}$ & $\begin{array}{c}\text { Cation } \\
\text { Mg }\end{array}$ & $\begin{array}{c}\mathrm{Mg} / \mathrm{L} \\
\mathrm{K}\end{array}$ & $\begin{array}{l}\text { Soluble } \\
\mathrm{HCO}_{3}\end{array}$ & $\begin{array}{l}\text { Anion } \\
\text { Cl }\end{array}$ & $\begin{array}{c}(\mathbf{m e q} / \mathbf{1}) \\
\mathrm{SO}_{4}\end{array}$ \\
\hline Sandy loam & 8.4 & 1.16 & 31.25 & 0.55 & 0.015 & 8.2 & 4.5 & 1.9 & 5.5 & 3.8 & 5.6 \\
\hline
\end{tabular}

Table 2. Chemical analysis of the organic manure (cattle manure) 


\begin{tabular}{lcccc}
\hline Component & N \% & P \% & K \% & O.M \% \\
\hline Cattle manure & 1.08 & 0.9 & 0.6 & 14 \\
\hline
\end{tabular}




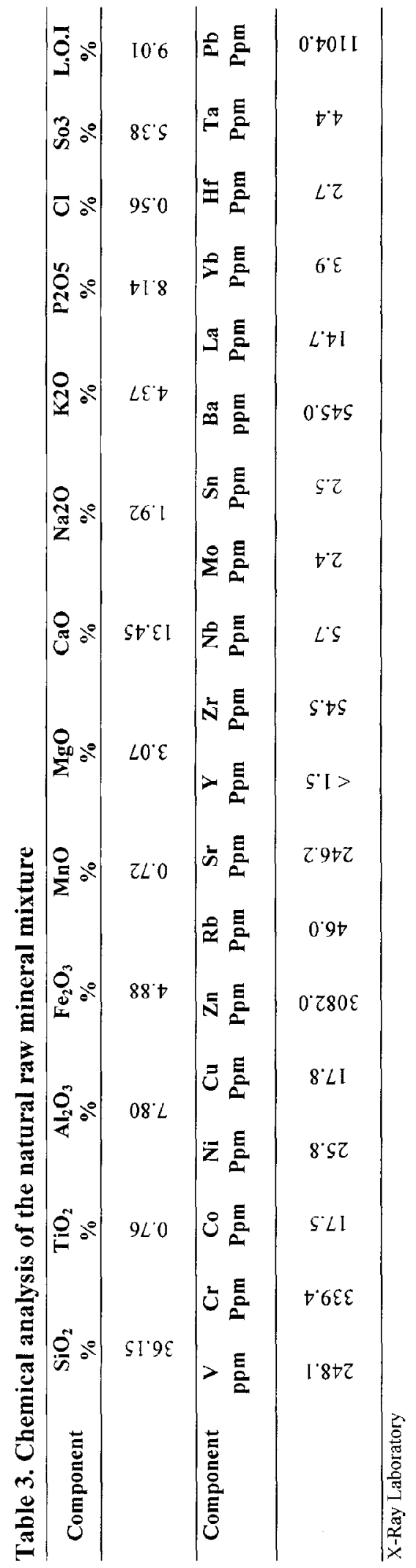


Table 4. The studied treatments

\begin{tabular}{|c|c|}
\hline No. & Treatments/ Tree \\
\hline T 1 & $\begin{array}{l}-1.5 \mathrm{~kg} \mathrm{NRMM} *+1 \mathrm{~kg} \mathrm{~A} . \mathrm{S}^{* *}+15 \mathrm{~kg} \text { cattle manure at December }+250 \mathrm{gm} \text { magnetite } \\
-1.5 \mathrm{~kg} \text { NRMM }+1 \mathrm{~kg} \text { A.S at June }\end{array}$ \\
\hline T 2 & $\begin{array}{l}-1.5 \mathrm{~kg} \text { NRMM }+1 \mathrm{~kg} \text { A.S + } 15 \mathrm{~kg} \text { cattle manure at December + } 500 \mathrm{gm} \text { magnetite } \\
-1.5 \mathrm{~kg} \text { NRMM }+1 \mathrm{~kg} \text { A.S at June }\end{array}$ \\
\hline T 3 & $\begin{array}{l}-1.5 \mathrm{~kg} \text { NRMM }+1 \mathrm{~kg} \text { A.S }+15 \mathrm{~kg} \text { cattle manure at December }+750 \mathrm{gm} \text { magnetite } \\
-1.5 \mathrm{~kg} \text { NRMM }+1 \mathrm{~kg} \text { A.S at June }\end{array}$ \\
\hline T 4 & $\begin{array}{l}-1.5 \mathrm{~kg} \mathrm{NRMM}+1 \mathrm{~kg} \text { A.S + } 15 \mathrm{~kg} \text { cattle manure at December }+1000 \mathrm{gm} \text { magnetite } \\
-1.5 \mathrm{~kg} \text { NRMM }+1 \mathrm{~kg} \text { A.S at June }\end{array}$ \\
\hline T5 & $\begin{array}{l}-15 \mathrm{~kg} \text { (Mixture of cattle manure }+\mathrm{N}, \mathrm{B}, \mathrm{K}, \mathrm{Mg} \text { and } \mathrm{S}){ }^{* * *}+2 \mathrm{~kg} \text { super phosphate triple }+250 \mathrm{~g} \\
\text { magnetite at December } \\
-1 \mathrm{~kg} \text { A.S after fruit set }+1 \mathrm{~kg} \text { A.S at May }+1 \mathrm{~kg} \text { A.S at August } \\
-3 / 4 \mathrm{Kg} \text { potassium sulphate at the first irrigation and } 3 / 4 \mathrm{~kg} \text { potassium sulphate at June. }\end{array}$ \\
\hline T 6 & $\begin{array}{l}-15 \mathrm{~kg} \text { (Mixture of cattle manure }+\mathrm{N}, \mathrm{P}, \mathrm{K}, \mathrm{Mg} \text { and } \mathrm{S} \text { ) } * * *+2 \mathrm{~kg} \text { super phosphate triple }+500 \mathrm{~g} \\
\text { magnetite at December } \\
-1 \mathrm{~kg} \text { A.S after fruit set }+1 \mathrm{~kg} \text { A.S at May }+1 \mathrm{~kg} \text { A.S at August } \\
-3 / 4 \mathrm{Kg} \text { potassium sulphate at the first irrigation and } 3 / 4 \mathrm{~kg} \text { potassium sulphate at June. }\end{array}$ \\
\hline T7 & $\begin{array}{l}-15 \mathrm{~kg} \text { (Mixture of cattle manure }+\mathrm{N}, \mathrm{P}, \mathrm{K}, \mathrm{Mg} \text { and } \mathrm{S} \text { ) } * * *+2 \mathrm{~kg} \text { super phosphate triple }+750 \mathrm{~g} \\
\text { magnetite at December } \\
-1 \mathrm{~kg} \text { A.S after fruit set }+1 \mathrm{~kg} \text { A.S at May }+1 \mathrm{~kg} \text { A.S at August } \\
\text { - } 3 / 4 \mathrm{Kg} \text { potassium sulphate at the first irrigation and } 3 / 4 \mathrm{~kg} \text { potassium sulphate at June. }\end{array}$ \\
\hline T 8 & $\begin{array}{l}-15 \mathrm{~kg} \text { (Mixture of cattle manure }+\mathrm{N}, \mathrm{P}, \mathrm{K}, \mathrm{Mg} \text { and } \mathrm{S}) * * *+2 \mathrm{~kg} \text { super phosphate triple }+1000 \mathrm{~g} \\
\text { magnetite at December } \\
-1 \mathrm{~kg} \text { A.S after fruit set }+1 \mathrm{~kg} \text { A.S at May }+1 \mathrm{~kg} \text { A.S at August } \\
-3 / 4 \mathrm{Kg} \text { potassium sulphate at the first irrigation and } 3 / 4 \mathrm{~kg} \text { potassium sulphate at June. }\end{array}$ \\
\hline $\begin{array}{l}\text { T } 9 \\
\text { (Control) }\end{array}$ & $\begin{array}{l}-15 \mathrm{~kg} \text { (Mixture of cattle manure }+\mathrm{N}, \mathrm{P}, \mathrm{K}, \mathrm{Mg} \text { and } \mathrm{S}) * * *+2 \mathrm{~kg} \text { super phosphate triple } \\
-1 / 2 \mathrm{~kg} \text { A.S after fruit set }+1 / 2 \mathrm{~kg} \text { A.S at May }+1 / 2 \mathrm{~kg} \text { A.S at August. } \\
-375 \text { potassium sulphate at the first irrigation and } 375 \mathrm{~kg} \text { potassium sulphate at June. }\end{array}$ \\
\hline
\end{tabular}

In each sample, fruit weight was recorded as (gm), fruit dimensions [length and diameter in $(\mathrm{cm})$ ], firmness was determined according to Magness and Taylor (1925) pressure tester using a 5/16" plunger. Total soluble solids (TSS\%) in juice were determined using a hand refractometer and the acidity percentage was determined according to AOAC (1980). Total sugar content $\%$ was determined according to Woodman (1941). At the end of the trial some fruit mineral composion was determined, by X-Ray laboratory.

The obtained data throughout the two studied growing seasons were statistically analyzed according to Sendecor and Cochran (1990) and L.S.D test at 0.05 levels was used for comparison between treatments.

\section{Vegetative growth:}

The vegetative growth of"Le Conte"pear trees (shoot length, diameter, and number and leaf area) in 2008 and 2009 are shown in Table (5). The data revealed that $\mathrm{T} 8$ significantly induced the highest values in both years followed by $\mathrm{T} 7, \mathrm{~T} 4$ and $\mathrm{T} 5$, respectively, (except for shoot length, T4 came before T7). The lowest effects were noticed in control trees.

\section{Leaf mineral composition:}

Tables (6\&7) indicated that the highest levels of leaf $\mathrm{N}, \mathrm{P}, \mathrm{K}, \mathrm{Ca}$ and $\mathrm{Fe}$ were obtained from trees under $\mathrm{T} 8$ followed by T7, T4 and T6 while T4 induced the highest leaf Mn and Zn followed by T3, T8, T7, T2, 

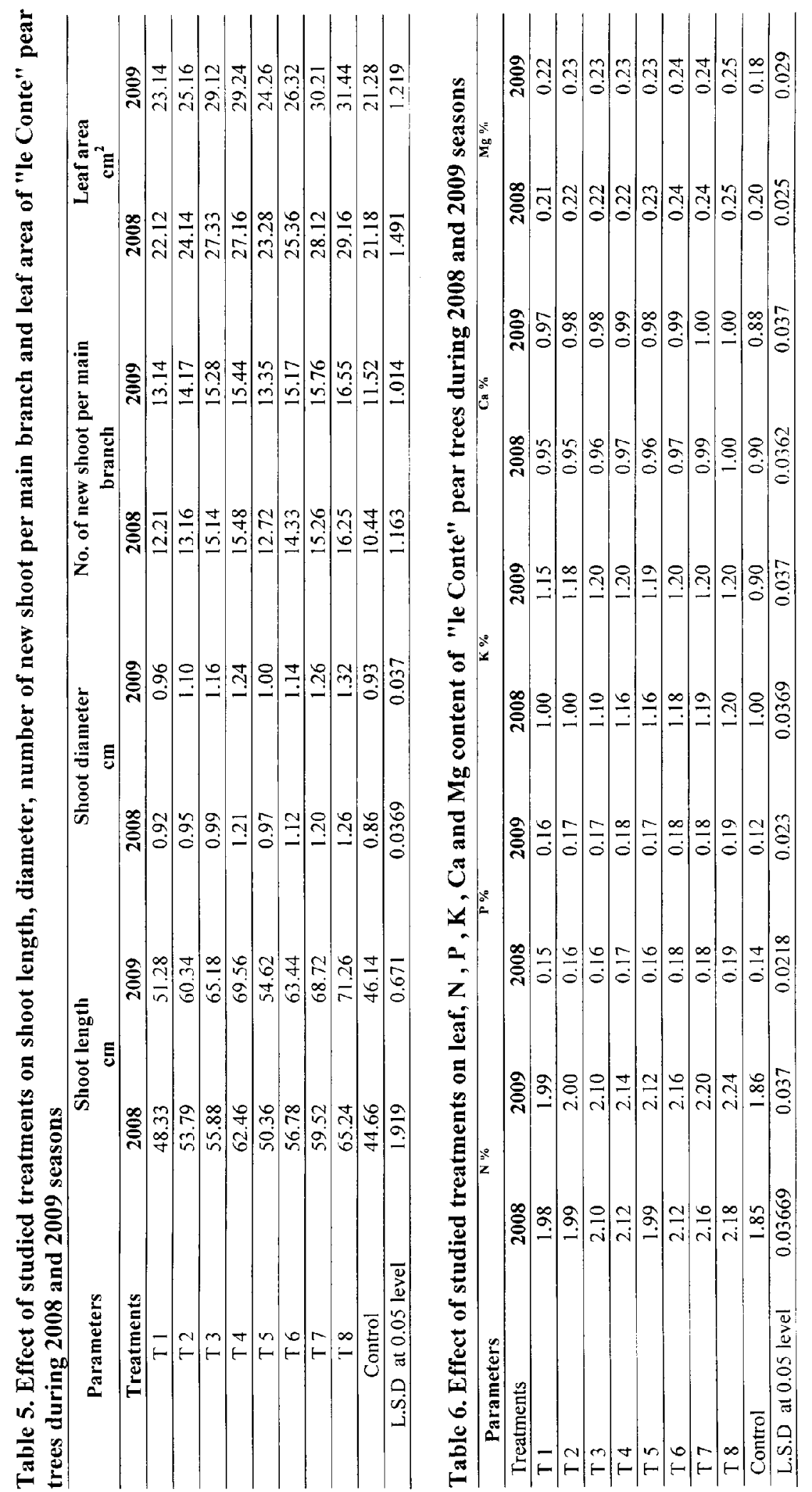


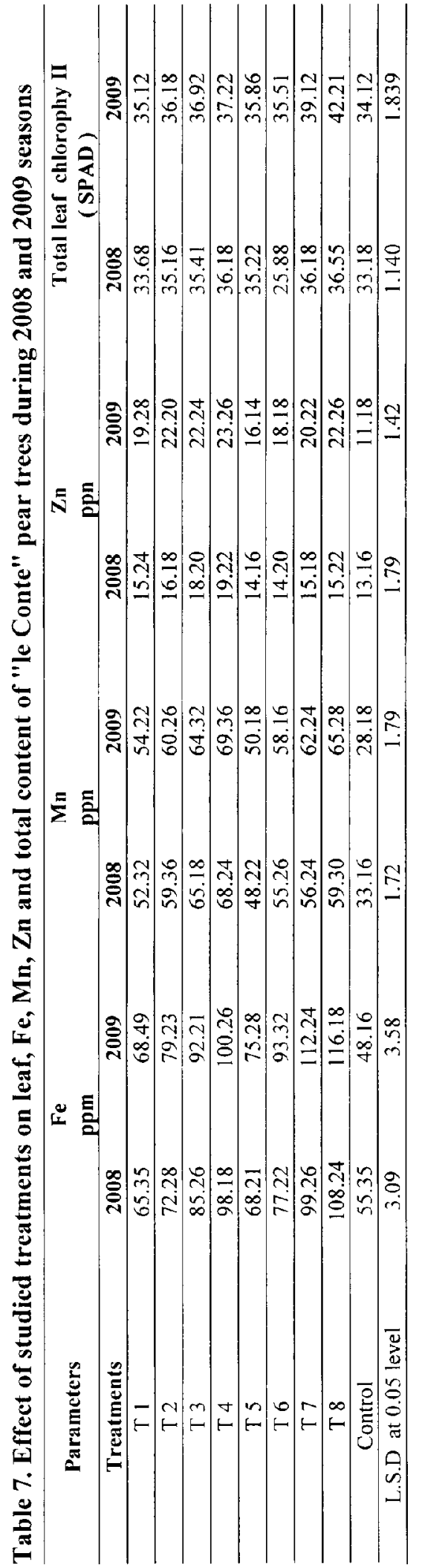


$\mathrm{T} 1$ and T5, meanwhile, the lowest levels were found in control trees in both years. Statistical analysis revealed that the differences were significant for $\mathrm{N}$ in both years and for $\mathrm{P}$ and $\mathrm{K}$ in the second year.

\section{Leaf total chlorophyll content (SPAD):}

Data in Table (7) illustrated that trees under T8 induced the highest total leaf chlorophyll content (SPAD) followed by T7, T4, \&T3 in the two studied years. The significance between differences was clear in the second year.

\section{Fruit yield:}

Table (9) indicated that T8 \& T7 (also T4 in 2008 only) induced the highest fruit yield / tree followed by T6, T3\& T2, while control trees induced the lowest effect in both years.

\section{Fruit quality:}

Physical and chemical properties are shown in Tables (8\&9). The differences between NPK and NRMM treatments were not statistically significant.

\section{Fruit mineral composition:}

Data in Table(11) indicated that according to significantly, the treatments could be arranged as the following descending order: T4> T3 $>\mathrm{T} 8>$ control $>\mathrm{T} 2$ $\& \mathrm{~T} 1$ and T7 > T6 \&T5 for Co and T4>T3>T2\&T1>T8, $\mathrm{T} 7$, control T6\&T5 for $\mathrm{Ni}$

\section{Effect of magnetite raw treatments:}

The obtained data cleared that increasing the applied rate of magnetite raw/tree significantly increased vegetative growth, leaf mineral composition, leaf total chlorophyll, and yield and fruit quality in the two seasons (combined with NRMM or NPK treatments).

\section{DISCUSSION}

The obtained data indicated that natural raw mineral mixture (NRMM) treatments significantly reduced shoot length in 2008 and shoot diameter in both years as compared with NPK treatments. Meanwhile, shoot number and leaf area in both seasons and leaf total chlorophyll (SPAD) in 2008 were not significantly affected Table (10). That may be mean limit differences between the studied treatments. As for leaf mineral content data in Table (10) cleared that NPK treatments significantly enhanced leaf $\mathrm{N} \& \mathrm{Fe}$ in both studied years and leaf $\mathrm{P} \& \mathrm{~K} \%$ in 2008 than did NRMM treatments. On the other side, NRMM treatments significantly enhanced leaf $\mathrm{Mn} \& \mathrm{Zn}$ in the two seasons. Moreover, data approved that NPK treatments significantly increased yield/ tree $(\mathrm{kg})$ by $5.9 \%$ and6.7\% in 2008 and 2009 ,respectively, than did NRMM treatments ,Meanwhile, fruit quality parameters (except TSS\% in2009) were not significant .Many investigators supported these findings, Badr, 2006, reported that could be used ,feldspar a potash mineral, which contain $11.25 \% \mathrm{~K} 2 \mathrm{O}$ in feeding plant. In addition, Abdel Rahman et al., 2009, mentioned that natural elements compound application significantly increased navel orange tree vegetative growth, fruit-set percentage tree yield and yield efficiency. As for positive effects of magnetite combined with NRMM or NPK treatments on the studied parameters, they are in line with those reported by Milewski, 2006. who mentioned that he used magnetic water and magnetite in the soil to stimulate the growth of plants. Data in Table(11) indicated that NRMM applications significantly enhanced fruit cobalt $(\mathrm{Co})$ and nickel $(\mathrm{Ni})$ as compared with NPK applications, while the differences were not significant for fruit lead $(\mathrm{Pb})$ in both years of study .However, the results revealed that the concentrations of these heavy metals were in the permissible limits. These data are supported with those found by El-Seginy and Attala, 1999.who reported that leaf lead $(\mathrm{Pb})$ of unpolluted pear trees planted in greenhouse was $2.37(\mathrm{ppm}) \& 2.61(\mathrm{ppm})$, while it was $3.50 \& 3.36$ (ppm) for road dust polluted trees in two successive seasons .Moreover, they mentioned that leaf nickel (Ni) of unpolluted pear trees was $2.02 \& 2.38$ (ppm) while it was $2.75 \& 2.53(\mathrm{ppm})$ for polluted trees with road dust in the same studied years, respectively.

\section{FEASIBILITY}

The findings of the present study indicated that the best treatment of NPK was T8 while, the best treatment of NRMM was T4, thus the following is the cost of each treatment:

The cost of $\mathrm{T} 8=3 \mathrm{~kg}$ ammonium sulphate $\mathrm{x}(2.0$ L.E) $+2 \mathrm{~kg}$ super phosphate triple $\mathrm{x}(1.75$ L.E $)+1 \mathrm{~kg}$ magnetite raw $x(4 \mathrm{~L} . \mathrm{E})+1.5 \mathrm{~kg}$ potassium sulphate $\mathrm{X}$ $(5.0 \mathrm{~L} . \mathrm{E})=6+3.5+4+5=18.5$ L.E/tree.

Cost of chemical fertilizers which added to cattle manure $=5.5$ L.E/tree. (Notice: $15 \mathrm{~m} 3 /$ Feddan cattle manure was used.).

Total cost of T8 $=18.5+5.5=24 \mathrm{~L} . \mathrm{E} /$ tree.

Total cost of $\mathbf{T} 4=3 \mathrm{~kg}$ NRMM x $(1.0 \mathrm{~L} . \mathrm{E})+2 \mathrm{~kg}$ ammonium sulphate $\mathrm{x}(2.0 \mathrm{~L} . \mathrm{E})+1 \mathrm{~kg}$ magnetite raw $x(4.0 \mathrm{~L} . \mathrm{E})=11.0$ L.E /tree.

[Remark: The cost of cattle manure was not considered because each studied tree was received the same amount of it.] .

\section{CONCLUSION}

Data obtained in this work approved that NRMM applications induced acceptable effects on the 
performance of "Le Conte" pear trees planted in calcareous soil as compared with NPK applications.
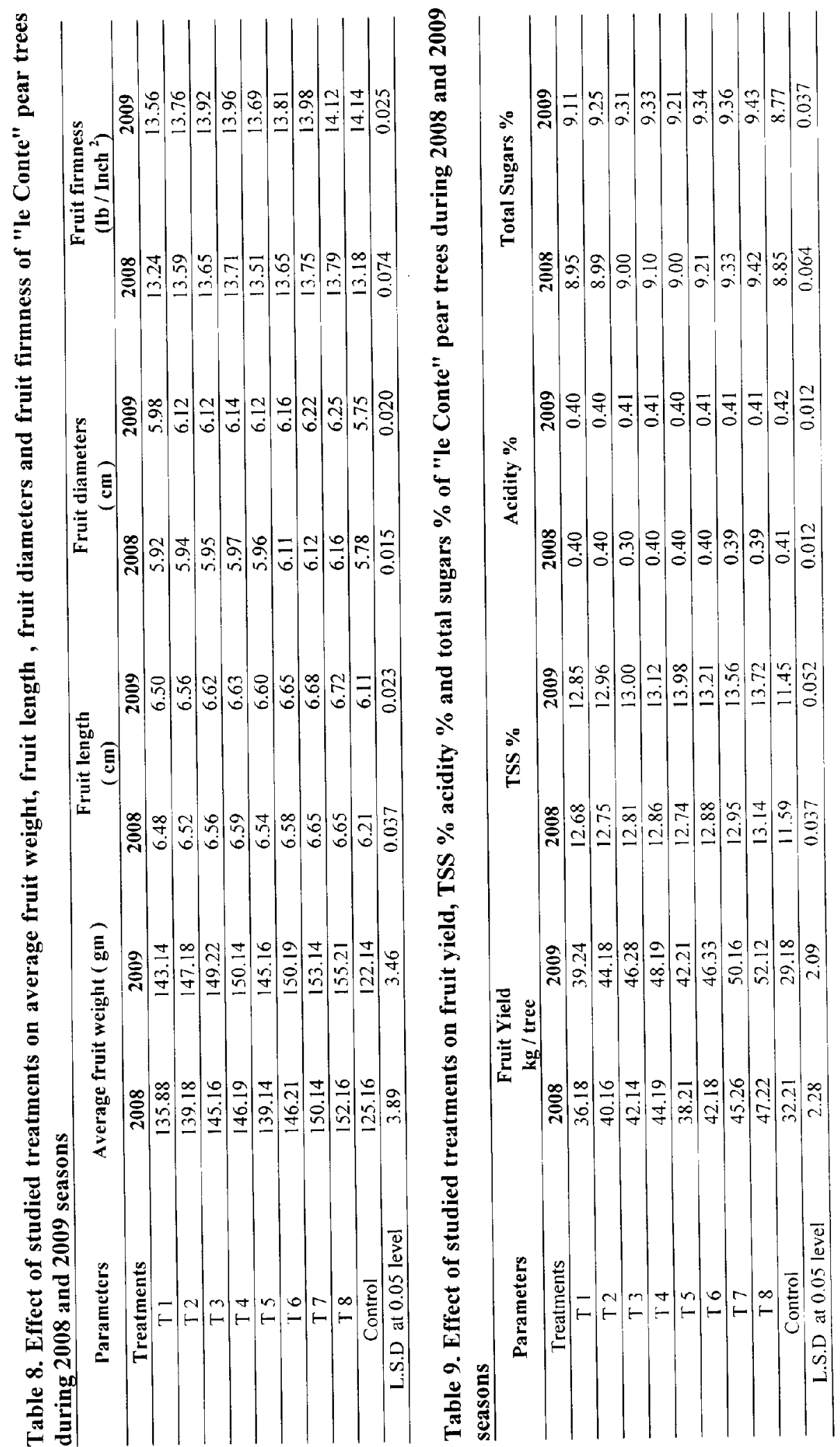


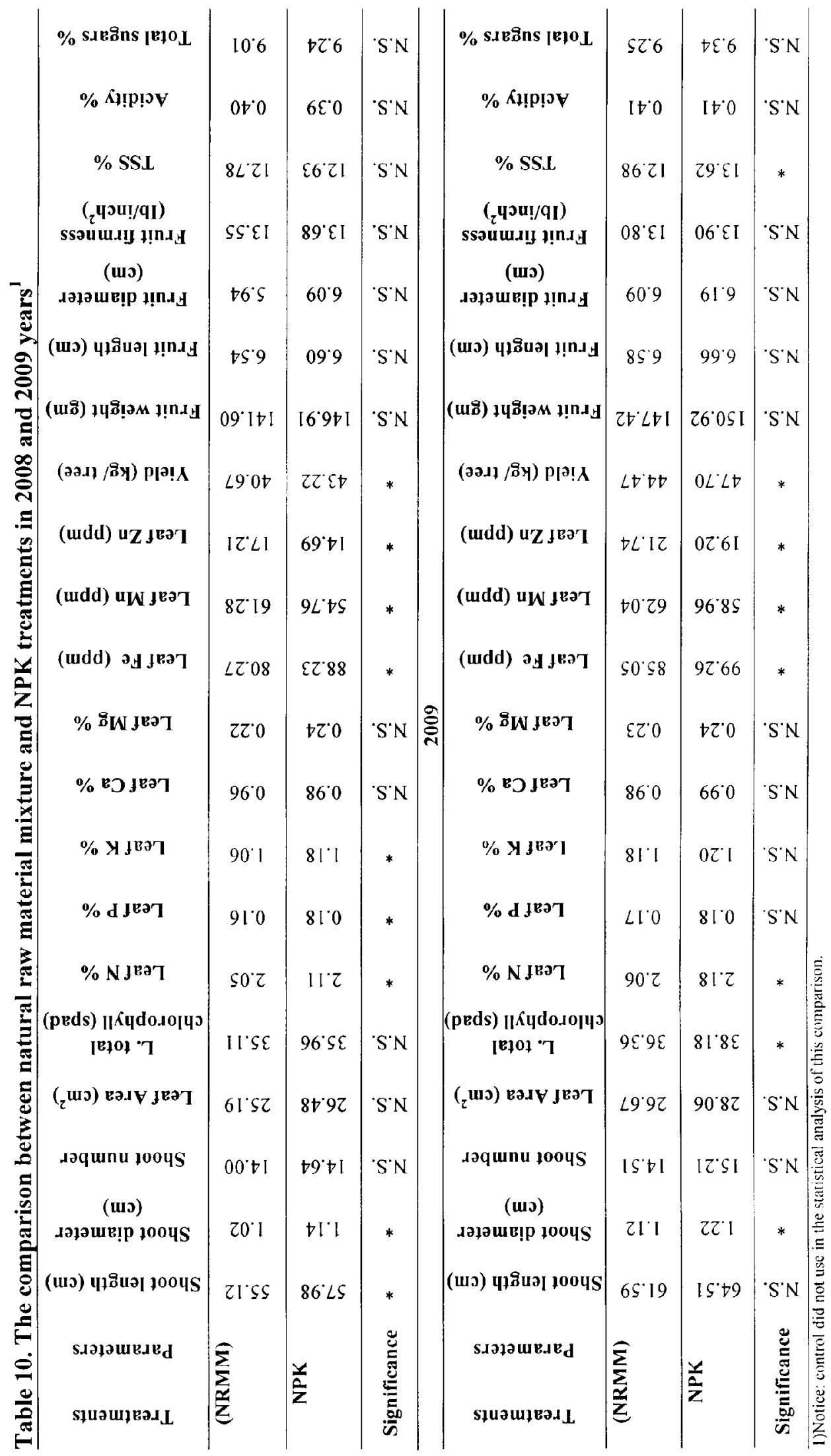




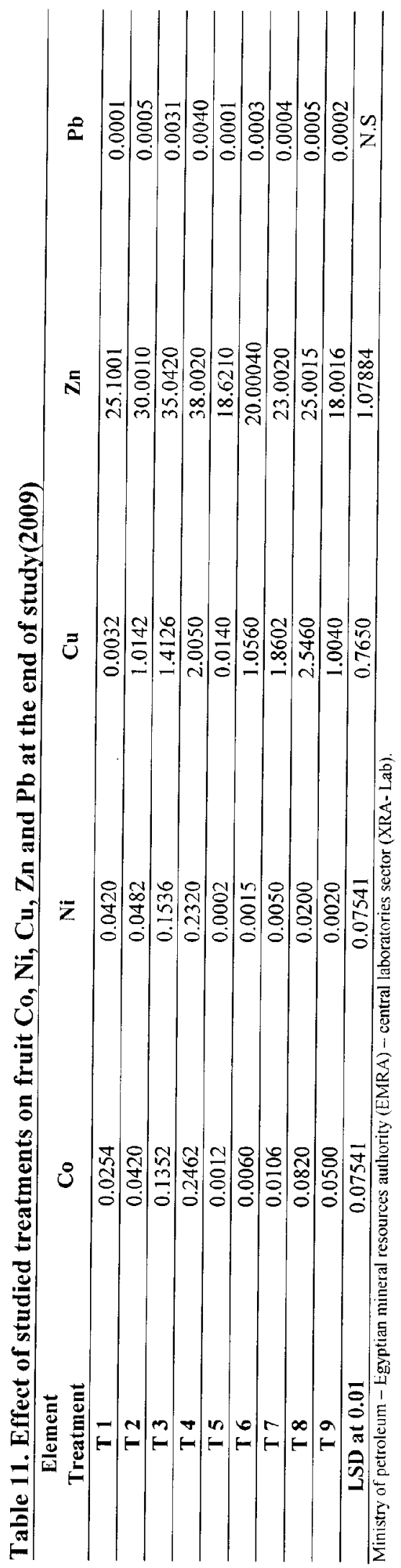


In addition, using magnetite raw in rate of $1 \mathrm{~kg} /$ tree combined with NRMM or NPK applications induced satisfactory results.

On the other side, studies carried out by the developed countries in the environment and in the general health field, approved that traditional methods in fertilization that depended basically and for a long time on chemical fertilizers have got side effect on the soil and the environment, eventually on human because it caused diseases. If the above mentioned points beside the cost of NRMM applications (NPK applications cost twice NRMM) taking into account, using NRMM and magnetite raw applications as a substitute for NPK fertilizers in feeding"Le Conte"pear trees are reasonable but it needs more investigations.

\section{REFERENCES}

Abdel Rahman, M.; A. El-Metwally and Y. Ibrahim.2009.Effect of natural elements compound applications on citrus trees and seedlings production.Egypt, J. of Appl. Sci., 24 (10A) 293-307.

Association of Official Agricultural Chemists.1980.Official methods of analysis (The A.O.A.C.13th ed. Washington, D.C., USA).

Badr, M.A.2006.Efficiency of K-feldspar combined with organic materials and silicate dissolving bacteria on Tomato yield. of Applied Sci. Res., 2(12):1191-1198.

Chang, K.L. and R.H.Bray.1951. Determination of calcium and magnesium in soil and plant materials. Soil Sci. 72:449-458.

Chapman, H.D. and P.F. Pratt.1961.Methods of analysis for soil, plant and root: shoot ratios.J.Hort.Sci. 46:121-130.
El-Azzouni, M.M.; Abd El-Latif, F.I. and Kenawi, E.A. (1975). Determination of maturity in Pear cultivars LeConte, Shoubra and Pine apple. Arch. Gartenban.23 (8):483-489.

El -Seginy, A.M. and E.S. Attala.1999. Effects of dust from different sources on vegetative growth and heavy metals content of some fruit seedling. Proceedings of the 1 st Congress, Cairo Univ.Fac .of Agric. 27-29 Nov. pp: 7882.

Evenhuis, B.1976. Nitrogen determination. Dept. Agric. Res., Royal Tropical Inst. Amsterdam.

Evenhuis, B and P.W. Dewaard.1980. Principles and practices in plant analysis. FAO .Soil Bull. 38(1):152-163.

Helial, B.M.; Y.N. Gobran and M.H. Moustafa (2003).Study on the effect of organic manure source, method of organic manure application and bio-fertilizers on tree growth and leaf mineral content of Washington Navel orange trees. Egypt, J. Apl. Sci., 18(4A), 270-296.

Magness, J.R. and G.F. Taylor. 1925. An improved type of pressure tester for the determination of fruit maturity. U.S.Dept.Agric. Circ. 359 8pp.

Milewsk, J.V.2006. The effect of magnetite, magnetic water and magnetic monopoles on plant growth. Ph.D. http:///www.Subtleenergies.Com/ormus/tw/magnetid water.htm.

Murphy, J. and P.Riley.1962. A modified single solution method for the determination of phosphorus in natural water .Anal. Chim. Acta 27:31-36.

Sendecor, G.W. and G.W. Cochran. 1990. Statistical methods.7th Ed., Iowa State Univ.USA.P.593.

Westwood, M.N.1988.Temperate-Zone Pomology .Timber Press.9999 S.W. Wilshire Portland, Oregon, 97225.P.181.

Woodman, A.G.1941. Food analysis.Mc Graw - Hill Book Company, Inc., New York. 


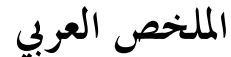

\section{استخدام مخلوط الخامات الطبيعيه وخام الماجنتيت (الحديد المغناطيسى) كبديل للاسمده الكيماويه في تغذية أشجار الكمثرى"ليكونت" المتزرعه في الارض الجيريه}

$$
\text { إيمان صبحى عطالله، وصفى ماهر عبد المسيح، جهاد بشرى يوسف }
$$

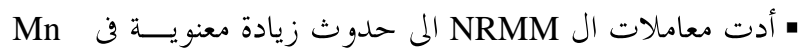

Zn (ppm) ال NPK زيادة معنوية في Fe (ppm) الورقة في عامى الدراسة.

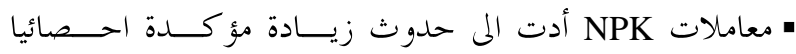

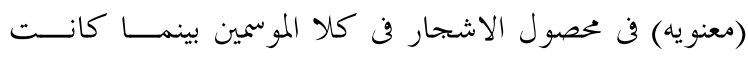
الفروق بين المعملات NPK ,NRMM غير معنويــــ بالنــسبة لصفات جودة الثمار. • أدت زيادة معدلات الأضافة من الحديد المغناطيسى الى حـــــــ

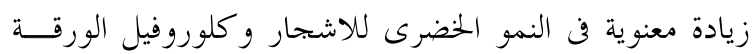

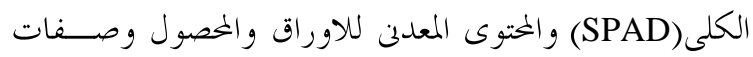

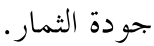
• أظهرت نتائج تحليل الثمار أن العناصر الثقيلة (الكوبلت- النيكل الرصاص) كانت في الحدود المصرح هها. هذا وقد كانت تكلفة

معاملات NPK تقريبا ضعف تكلفة معاملات NRMM. خلصت الدراسة المى أن استخدام مخلوط الخامـــات الطبيعيـــة

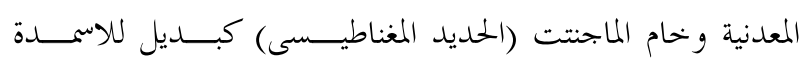

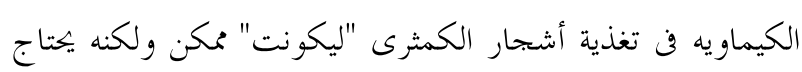
الى المزيد من الدراسة.
أجرى هذا العمل في عامى ^ . . r و9 . . r لدراسة امكانيــة استخدام مخلوط الخامات الطبيعيه المعدنيه (NRMM) وخام الحديد المغناطيسى كبديل للاسمده الكيماويســ NPK في تغذيــة أشــار

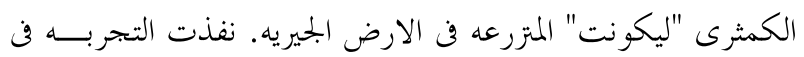

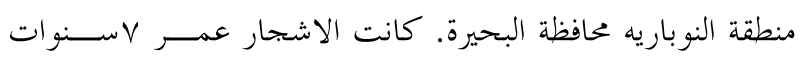

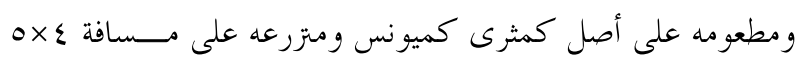
متر. م معاملات (ع معاملات NRMM + مع معــاملات NRK بجانب الكنترول قد استخدمت وقد أعطيت كل المعاملات فيما عدا الكنترول حديد مغناطيسى بمعدلات مختلفه كما يلى: .0ب و . ..

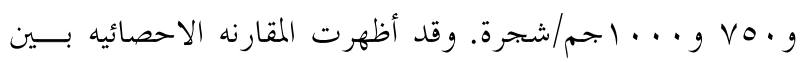
معاملات NRM , NRM النقاط التاليه: • معاملات NPK أحدثت زياده معنويه فن قطر النموات الحديثه في عامى الدراسة وفى طول النمات الحديثة في السنة الاولى فقط.

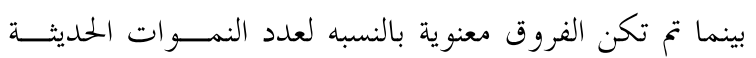
ومساحة الورقة. أيضا أعطت معاملات NPK زيادة معنوية في K و الورقة في عامى الدراسة وزيادة معنويسـة في الم\% N\% الورقة في السنة الاولى فقط. 